\title{
A study on Air Passenger demand Forecasting from Egypt to Suadi Arabia
}

\author{
M. M. Mohie El-Din, N. I. Ghali, A. Sadek and A. A. Abouzeid \\ Department of Mathematics, Faculty of science, Al-Azhar University \\ Nasr City, Cairo 31884, Egypt
}

\begin{abstract}
This study employed the back-propagation neural network to forecast the air passenger demand from Egypt to Saudi Arabia. The factors that influence air passenger are identified, evaluated and analyzed by applying the back-propagation neural network on the annual data 2000 to 2010 by using visual gene developer package.
\end{abstract}

\section{General Terms}

Air Passenger Traffic

\section{Keywords}

Airline Passenger Demand Forecasting, Artificial Neural Network

\section{INTRODUCTION}

Airlines always develop operating strategies regarding to fleet capacity, routing, destination, routes and human resources. The success of the strategies depend strongly on air traffic demand forecasting. Forecasting air traffic demand is the ability to predict the number of airline passengers from/to airport or by carrier during future period of time. Many different literature was introduced to model the air passenger demand. Bons et al.[1] collected 37 studies and 204 observations, and indicated that air passenger demand is largely determined by spending capacity of customers. Hsu and Wen[2] develop time series $\operatorname{GM}(1,1)$ models by using grey theory to forecast total number of passengers in 10 country-pair traffic. In addition, Hsu and Wen [3] apply grey theory and multi-objective programming to develop series of models to forecast airline city-pair passenger traffic. Grosche et al.[4] presented two gravity models to estimate the air passenger volume between city-pairs. Kuo et al.[5] employed artificial neural network(ANN) to establish a mathematical model with multiple inputs and multiple outputs, and the results indicated that this model may accurately forecast the air transport demand for routes. BaFail [6] develop a forecasting model to forecast the number of airline passengers (international and domestic) in five major cities on Saudi Arabia by artificial neural network and the results indicated that the oil gross domestic product, population size and per capita income were found to be the most contributing variables that affect the number of passengers in Saudi Arabian airline sectors. Kuo and Chen[7] employed artificial neural networks to forecast the airline passenger and the air cargo demand from Japan to Taiwan, the results show that some factors influence both passenger and cargo demand, and the others only one of them. The employed population in Japan and per capita income(PCI) in Taiwan influence both air passenger and air cargo volume. Flight movement from Tokyo(NRT) to Taipei(TPE), PCI in Taiwan and foreign exchange rate are the three most important factors for passengers volume. On the other hand Mohie El-Din et al.|[8] developed a stochastic dynamic programming model to optimize airlines decisions regarding purchasing, leasing and disposing aircraft over a period of time based on passenger demand forecasting and apply the research on EGYPTAIR Airlines company, as extension to this research the current research aim to employed artificial neural network to forecast the air passenger from Egypt to Saudi Arabia by using back-propagation neural network. This paper is organized as follows: Section 2 present the air travel market analysis. The Artificial Neural Network is discussed in section 3 Experimental results and evaluation are presented in Section 4 Concluding remarks are given in Section 5

\section{AIR TRAVEL DEMAND ANALYSIS}

Analyzing air travel demand is an integral part of an airlines plan that reflects the fleet capacity utilization, which will be considered to make decisions. Regarding to maximum utilization of fleet capacity ,it is important to forecast the volume of air passenger demand in the future. According to Lyneis[10], the air travel demand can be affected by two factors, e.g. external and internal factors. Assumption about future demand and performance are essential for business decisions. He considered airfare as the internal factor, and Gross Domestic Product (GDP) and population as the external factors. Miller and Clarke[11] have developed a model to evaluate the strategic value of air transportation infrastructure. They considered airfare impact and level of service impact as the internals variables that affect the air travel demand. Law and Au[12] predict Japanese demand for travel to Hong Kong. The independent variables in their work included service price in Hong Kong relative to Japan, foreign exchange rate, population in Japan, marketing expenses to promote Hong Kong's tourism industry, real gross domestic expenditure per person in Japan, and average hotel rate in Hong Kong .Air travel demand can be affected by many different variables, the literature survey shows that population in Egypt, employed population in Egypt, per capita income(PCI) in Egypt, Gross domestic product (GDP) in Egypt, gross national product(GNP) in Egypt, economic growth rate in Egypt, foreign exchange rate, flight movement from Cairo to Riyadh and consumer price index(CPI) in Saudi are the most commonly used independent variables for forecasting air passenger demand from Egypt to Saudi Arabia.

\section{ARTIFICIAL NEURAL NETWORK}

A neural network consists of an input layer, an output layer, and usually one or more hidden layers. Each of these layers contains nodes, and these are connected to other nodes at adjacent layers [9]. The purpose of a neural network is to learn to recognize patterns in a given data. Once the neural network has been trained on samples of the given data, it can make predictions by detecting similar patterns in future data. Fig. 1 illustrates a neural network with three layers. Each node in a neural network is a processing unit. The output from a given neuron is calculated by applying a transfer function to a weighted summation of its input to give an output. In this study, the summation function is the weighted summation.

$$
I_{j}=\sum_{i} W_{i j} X_{i}
$$


The activity function represents the output of the summation function.

$$
\text { net }_{j}=I_{j}
$$

The nonlinear transfer function has a sigmoid shape.

$$
Y_{j}=\frac{1}{1+\exp ^{- \text {net }_{j}}}
$$

Because the output range of the sigmoid function is between 0 and 1, the mapping of data is more suitable. Nodes in the input layer represent independent variables of the problem, including the appropriate social and economic parameters. The hidden layer is used to add an internal representation of nonlinear data. In general, the number of nodes in the hidden layer is determined by the arithmetic or geometric mean of the nodes in the input and output layers. In this research, the arithmetic mean was used for fast convergence and stable performance. The output of a neural network is the solution to a problem. In this study, the numeric values from the output nodes were used to represent air passenger. The energy function is a verification function which determines if the network energy has converged to its minimum. Whenever the energy function approaches zero, the network approaches its optimum solution.

$$
E=\frac{1}{2} \sum_{j=1}^{n}\left(T_{j}-Y_{j}\right)^{2}
$$

where $T_{j}$ is the actual observation, $Y_{j}$ is the predicted value, and $n$ is the number of predictions. The gradient steepest descent method was employed to find the minimum of the energy function. Back-propagation network (BPN) is one of the most commonly used supervised Artificial neural network(ANN) models. BPN is a layered feed-forward supervised network which is suitable for use in the air passenger forecasting models presented in this study. Neural network model can be programmed from scratch, the availability of neural network software packages makes the process easier. These packages supply predefined neural network architectures, like back propagation, and include algorithms to handle the delicate iterative computation of neural network weights. In this paper the visual gene developer package is utilized. Visual Gene Developer is a specialized gene design software that has many functions to analyze, design, and optimize genes. Originally, the software was developed to optimize DNA sequence (mainly for codon optimization) of our target genes and has been upgraded to be the general software package since 2008. In order to make use of the latest programming technology, we migrated programming language to Visual Studio .Net (dot net) framework and re-designed all program source codes to accommodate new features such as user-defined module development and artificial neural network prediction tool. Mean square error (MSE) were used to evaluate the forecasting performance of neural network, $M S E=\frac{1}{n} \sum_{j=1}^{n}\left(T_{j}-Y_{j}\right)^{2}$.

\section{EXPERIMENTAL RESULTS AND EVALUATION}

Section 2 has introduce the variables that affect on air passenger demand from Egypt to Saudi Arabia. All input variables were collected through a literature survey, market analysis and preliminary evaluation. The preliminary selection of data for the neural network was based on representative social and economic parameters, data availability, the reliability of data sources, and the measurability of variables in the modeling process. Table 1 containing the relevant data for forecasting air passenger demand from Egypt to Saudi Arabia in the period of 2000 to 2010, was set up based on public sources. The data period 2000 until 2007 is used for learning process the other period is used for evaluation. The candidate variables population in Egypt, employed population in Egypt, PCI in Egypt, GDP in Egypt, GNP in Egypt, Eco- nomic growth rate in Egypt, foreign exchange rate, flight movement from Cairo to Riyadh, CPI in Saudi are all used in the input layer. The output variable in this research which is air passenger demand from Egypt to Saudi Arabia is used in the output layer. In this study, three nodes are used in the hidden layer for fast convergence and stable performance, which is used to determine air passenger demand. Fig.2 provides a graphical presentation of the empirical findings with the BPN air passenger demand forecasting model. The blue line is the actual observation and the red line is the predicted value. Table 2 display the actual versus predicted values after BPN implementation. After the model is evaluated with 9 candidate input variables, we will analyze the affects of deleting one or more of these input variables on air passenger demand. Table 3 shows the different alternatives of deleting input variables and the corresponding MSE value. If the deleting of a candidate variable reduces the MSE value, then it interferes with air passenger demand forecasting and thus should be excluded from the BPN model. After deleting PCI in Egypt, GDP in Egypt, Flight movement from Cairo to Riyadh and CPI in Saudi, the BPN model can more accurately forecast with MSE $=9.80 \times 10^{-5}$, as shown in Table 3 The cross symbol indicates the input variables are included in the BPN model. Fig. 3 provides a graphical presentation of the empirical findings with the BPN air passenger demand forecasting model after deleting the four mentioned input variables.

\section{CONCLUSIONS}

In the current study, back-propagation neural networks were employed to forecast air passenger demand from Egypt to Saudi Arabia. The back-propagation neural network can accurately forecast air passenger demand. Men square error(MSE) is the selected criterion to evaluate forecasting performance after analyzing the empirical results. The results indicated that all selected input variables can not grantee forecast accuracy, some of input variables have no effect on forecasting accuracy and the others are required to grantee the accuracy. Population in Egypt, employed population in Egypt, GNP in Egypt, economic growth rate in Egypt and foreign exchange rate in Egypt were found to be the fifth most important factors for air passenger demand forecasting in the empirical analysis, moreover the input variable PCI in Egypt have the least effect on air passenger demand accuracy.

\section{REFERENCES}

[1] Brons, M., Pels, E., Nijkamp, P., Rietveld, P., 2002. Price elasticities of demand for passenger air travel: a metaanalysis. Journal of Air Transport Management, 8, 165-175.

[2] Hsu, C. I., Wen, Y. H., 1998. Improved grey prediction models for the trans-Pacific air passenger market. Transportation Planning and Technology, 22, 87-107.

[3] Hsu, C. I., Wen, Y. H., 2000. Application of grey theory and multiobjective programming towards airline network design. European Journal of Operational Research, 127, 44-68.

[4] Grosche, T., Rothlauf, T., Heinzl, A., 2007. Gravity models for airline passenger volume estimation. Journal of Air Transport Management, 13, 175-183.

[5] Kuo, S. Y., Shiau, L. C., Chang, Y. P., 2010. Air transport demand forecasting in routes network by artificial neural networks. Journal of Aeronautics Astronautics and Aviation Series $\mathrm{B}, 42,67-72$. (in Chinese).

[6] BaFail, A. O., 2004. Applying data mining technologies to forecast number of airline passengers in Saudi Arabia (domestic and international travels). Journal of Air Transportation. 


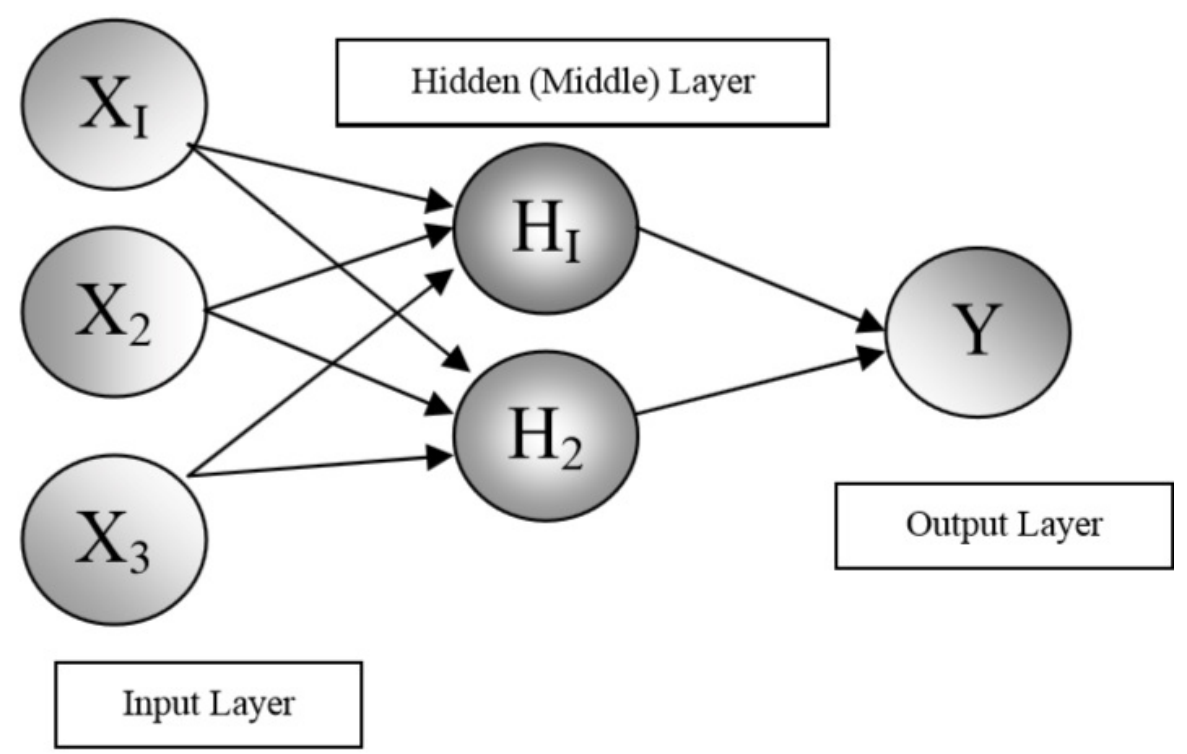

Fig. 1. Artificial Neural Network.

Table 1. Candidate input variables and output variable for air passenger demand

\begin{tabular}{|c|c|c|c|c|c|c|c|c|c|c|}
\hline Year & $\begin{array}{c}\text { Population } \\
\text { in Egypt } \\
(\mathrm{M})\end{array}$ & $\begin{array}{c}\text { Employed } \\
\text { population } \\
\text { in Egypt }\end{array}$ & $\begin{array}{c}\text { PCI } \\
\text { in } \\
\text { Egypt } \\
\text { USD }\end{array}$ & $\begin{array}{c}\text { GDP } \\
\text { in } \\
\text { Egypt } \\
\text { M USD }\end{array}$ & $\begin{array}{c}\text { GNP } \\
\text { in } \\
\text { Egypt } \\
\text { M }\end{array}$ & $\begin{array}{c}\text { Economic } \\
\text { growth } \\
\text { rate } \\
\text { in Egypt }\end{array}$ & $\begin{array}{c}\text { Foreign } \\
\text { exchange } \\
\text { rate } \\
\text { USD/EGP }\end{array}$ & $\begin{array}{c}\text { Flight } \\
\text { movement } \\
\text { from Cairo } \\
\text { to Riyadh }\end{array}$ & $\begin{array}{c}\text { CPI } \\
\text { in } \\
\text { Saudi } \\
\text { passenger } \\
\text { demand } \\
\text { from Egypt } \\
\text { to Saudi }\end{array}$ \\
\hline 2000 & 66.14 & 19.40 & 1140.12 & 99840 & 413300 & 5 & 4.40 & 1185 & 87.5 & 522750 \\
\hline 2001 & 67.2 & 18.80 & 1150.90 & 97630 & 438400 & 2.5 & 4.50 & 1190 & 85 & 531000 \\
\hline 2002 & 68.3 & 21.50 & 1161.67 & 87850 & 451200 & 1.7 & 4.63 & 1200 & 85 & 540000 \\
\hline 2003 & 69.43 & 20.80 & 1187.80 & 82920 & 473800 & 3.1 & 5.90 & 1370 & 85.5 & 580500 \\
\hline 2004 & 70.59 & 21.20 & 1216.11 & 78850 & 506000 & 4.5 & 6.20 & 1390 & 86 & 591000 \\
\hline 2005 & 71.78 & 20.50 & 1249.49 & 89690 & 545600 & 4.9 & 5.70 & 1350 & 87 & 592500 \\
\hline 2006 & 72.99 & 20.40 & 1312.82 & 107500 & 605500 & 6.8 & 5.70 & 1425 & 88 & 618750 \\
\hline 2007 & 74.23 & 21.60 & 1382.41 & 130500 & 668400 & 7.1 & 5.55 & 1410 & 90 & 659250 \\
\hline 2008 & 75.49 & 20 & 1456.57 & 162800 & 729600 & 7.2 & 5.42 & 1390 & 96 & 658350 \\
\hline 2009 & 76.78 & 21.60 & 1499.34 & 189000 & 763900 & 4.6 & 5.50 & 1395 & 105 & 657750 \\
\hline 2010 & 78.08 & 17.70 & 1550.24 & 218900 & 796300 & 5.1 & 5.60 & 1400 & 109 & 660000 \\
\hline
\end{tabular}

[7] Kuo, S. Y., chen, S. C., 2011. Air Passenger and Air Cargo Demand Forecasting: Applying Neural Network ro Evaluating Input Variables.

[8] Mohie El-Din, M. M., Ghali, N. I., Sadek, A., Abouzeid, A. A., 2015. Decision Support System for Airlines Fleet Capacity Management. International Journal of Computer Applications.

[9] Masters, T., 1993. Practical Neural Network Recipes in C++. Academic Press, Boston.

[10] Lyneis, J., 2000. System dynamics for market forecasting and structural analysis. System Dynamics Review, 16, 325.

[11] Miller, B., Clarke, J. P., 2007. The hidden value of air transportation infrastructure. Technological Forecasting and Social Science, 74, 1835.

[12] Law, R., Au, N., 1999. A neural network model to forecast Japanese demand for travel to Hong Kong. Tourism Management, 20, 89-97. 
Communications on Applied Electronics (CAE) - ISSN : 2394 - 4714

Foundation of Computer Science FCS, New York, USA

Volume 3 - No. 1, October 2015 - www.caeaccess.org

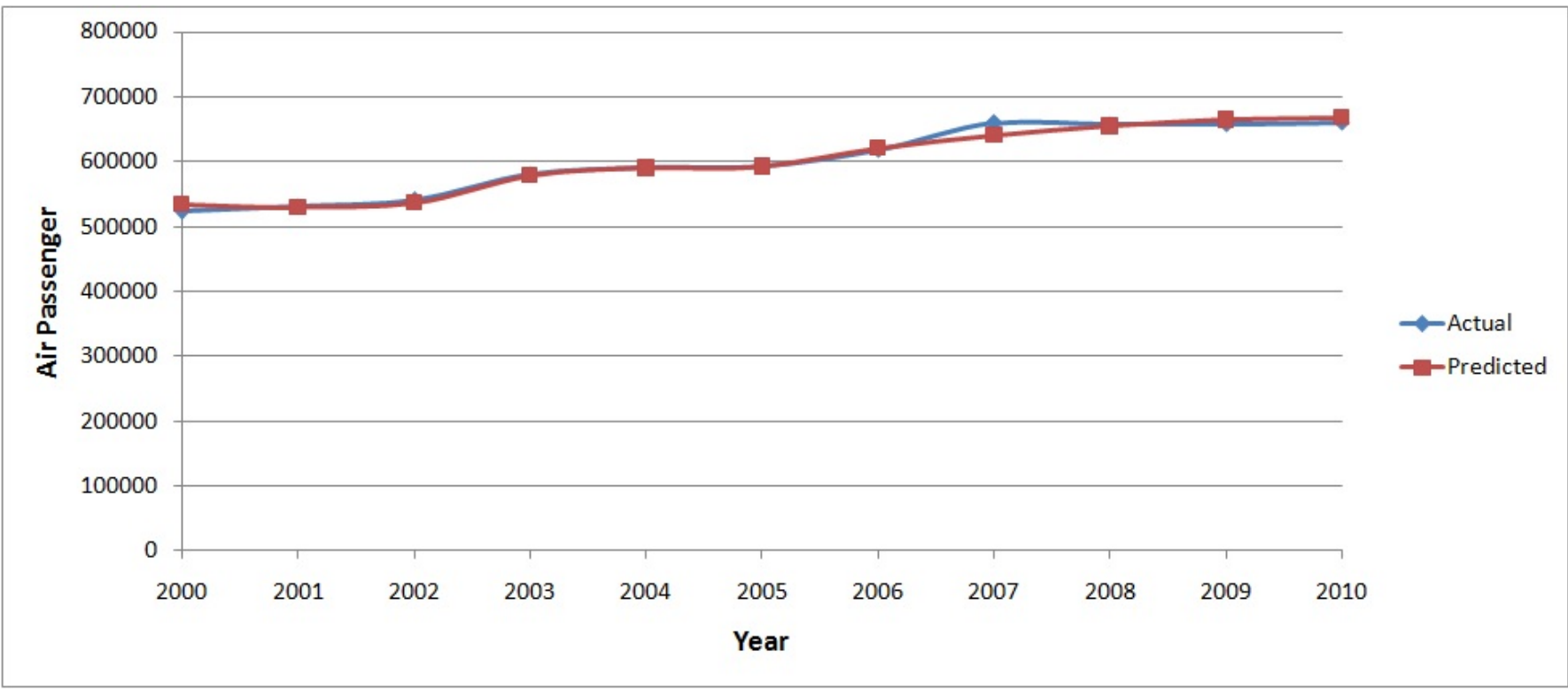

Fig. 2. Air Passenger Demand Forecasting.

Table 2. Actual and Predicted values After BPN Implementation

\begin{tabular}{|c|c|c|c|c|c|c|c|c|c|c|c|}
\hline Year & 2000 & 2001 & 2002 & 2003 & 2004 & 2005 & 2006 & 2007 & 2008 & 2009 & 2010 \\
\hline Actual & 522750 & 531000 & 540000 & 580500 & 591000 & 592500 & 618750 & 659250 & 658350 & 657750 & 660000 \\
\hline Predicted & 534026 & 529861 & 536223 & 578517 & 589867 & 592344 & 621578 & 640966 & 654158 & 664640 & 668604 \\
\hline
\end{tabular}

Table 3. The effects of deleting input variables on air passenger demand

\begin{tabular}{|c|c|c|c|c|c|c|c|c|c|}
\hline $\begin{array}{c}\text { Population } \\
\text { in Egypt } \\
\text { (M) }\end{array}$ & $\begin{array}{c}\text { Employed } \\
\text { population } \\
\text { in Egypt }\end{array}$ & $\begin{array}{c}\text { PCI } \\
\text { in } \\
\text { Egypt } \\
\text { USD }\end{array}$ & $\begin{array}{c}\text { GDP } \\
\text { in } \\
\text { Egypt } \\
\text { M USD }\end{array}$ & $\begin{array}{c}\text { GNP } \\
\text { in } \\
\text { Egypt } \\
\text { M }\end{array}$ & $\begin{array}{l}\text { Economic } \\
\text { growth } \\
\text { rate } \\
\text { in Egypt }\end{array}$ & $\begin{array}{c}\text { Foreign } \\
\text { exchange } \\
\text { rate } \\
\text { USD/EGP }\end{array}$ & $\begin{array}{c}\text { Flight } \\
\text { movement } \\
\text { from Cairo } \\
\text { to Riyadh }\end{array}$ & $\begin{array}{c}\text { CPI } \\
\text { in } \\
\text { Saudi }\end{array}$ & $\begin{array}{c}\text { Mean } \\
\text { Square } \\
\text { Error }\end{array}$ \\
\hline $\mathrm{X}$ & $\mathrm{X}$ & $\mathrm{X}$ & $\mathrm{X}$ & $\mathrm{X}$ & $\mathrm{X}$ & $\mathrm{X}$ & $\mathrm{X}$ & $\mathrm{X}$ & $9.88 \times 10^{-5}$ \\
\hline & $\mathrm{X}$ & $\mathrm{X}$ & $\mathrm{X}$ & $\mathrm{X}$ & $\mathrm{X}$ & $\mathrm{X}$ & $\mathrm{X}$ & $\mathrm{X}$ & $1.63 \times 10^{-4}$ \\
\hline$X$ & & $\mathrm{X}$ & $\mathrm{X}$ & $X$ & $X$ & $\mathrm{X}$ & $\mathrm{X}$ & $\mathrm{X}$ & $1.24 \times 10^{-} 4$ \\
\hline$X$ & $\mathrm{X}$ & & $X$ & $\mathrm{X}$ & $X$ & $\mathrm{X}$ & $X$ & $X$ & $7.74 \times 10^{-5}$ \\
\hline $\mathrm{X}$ & $\mathrm{X}$ & $\mathrm{X}$ & & $\mathrm{X}$ & $\mathrm{X}$ & $\mathrm{X}$ & $\mathrm{X}$ & $\mathrm{X}$ & $8.53 \times 10^{-} 5$ \\
\hline $\mathrm{X}$ & $\mathrm{X}$ & $\mathrm{X}$ & $\mathrm{X}$ & & $X$ & $\mathrm{X}$ & $\mathrm{X}$ & $X$ & $1.60 \times 10^{-} 4$ \\
\hline$X$ & $\mathrm{X}$ & $X$ & $X$ & $\mathrm{X}$ & & $\mathrm{X}$ & $X$ & $X$ & $1.43 \times 10^{-4}$ \\
\hline$X$ & $\mathrm{X}$ & $X$ & $X$ & $\mathrm{X}$ & $\mathrm{X}$ & & $X$ & $X$ & $1.21 \times 10^{-} 4$ \\
\hline $\mathrm{X}$ & $\mathrm{X}$ & $\mathrm{X}$ & $\mathrm{X}$ & $\mathrm{X}$ & $\mathrm{X}$ & $\mathrm{X}$ & & $\mathrm{X}$ & $7.96 \times 10^{-} 5$ \\
\hline $\mathrm{X}$ & $\mathrm{X}$ & $\mathrm{X}$ & $\mathrm{X}$ & $\mathrm{X}$ & $\mathrm{X}$ & $\mathrm{X}$ & $\mathrm{X}$ & & $8.82 \times 10^{-5}$ \\
\hline $\mathrm{X}$ & $\mathrm{X}$ & & & $\mathrm{X}$ & $\mathrm{X}$ & $\mathrm{X}$ & $\mathrm{X}$ & $\mathrm{X}$ & $1.00 \times 10^{-} 4$ \\
\hline $\mathrm{X}$ & $\mathrm{X}$ & $\mathrm{X}$ & & $\mathrm{X}$ & $\mathrm{X}$ & $\mathrm{X}$ & & $\mathrm{X}$ & $9.31 \times 10^{-5}$ \\
\hline $\mathrm{X}$ & $\mathrm{X}$ & & $\mathrm{X}$ & $\mathrm{X}$ & $\mathrm{X}$ & $\mathrm{X}$ & & $\mathrm{X}$ & $9.19 \times 10^{-5}$ \\
\hline$X$ & $\mathrm{X}$ & & & $\mathrm{X}$ & $\mathrm{X}$ & $\mathrm{X}$ & & $\mathrm{X}$ & $1.79 \times 10^{-} 4$ \\
\hline$X$ & $\mathrm{X}$ & $\mathrm{X}$ & & $\mathrm{X}$ & $\mathrm{X}$ & $\mathrm{X}$ & & & $9.13 \times 10^{-5}$ \\
\hline $\mathrm{X}$ & $\mathrm{X}$ & & $\mathrm{X}$ & $\mathrm{X}$ & $\mathrm{X}$ & $\mathrm{X}$ & & & $8.66 \times 10^{-} 5$ \\
\hline $\mathrm{X}$ & $\mathrm{X}$ & & & $\mathrm{X}$ & $\mathrm{X}$ & $\mathrm{X}$ & $\mathrm{X}$ & & $9.25 \times 10^{-5}$ \\
\hline $\mathrm{X}$ & $\mathrm{X}$ & & & $\mathrm{X}$ & $\mathrm{X}$ & $\mathrm{X}$ & & & $9.80 \times 10^{-5}$ \\
\hline
\end{tabular}

Note: The cross symbol indicate that the input variable included in the back propagation model

Table 4. Actual and Predicted values after deleting four input variables

\begin{tabular}{|c|c|c|c|c|c|c|c|c|c|c|c|}
\hline Year & 2000 & 2001 & 2002 & 2003 & 2004 & 2005 & 2006 & 2007 & 2008 & 2009 & 2010 \\
\hline Actual & 522750 & 531000 & 540000 & 580500 & 591000 & 592500 & 618750 & 659250 & 658350 & 657750 & 660000 \\
\hline Predicted & 522637 & 530036 & 543099 & 57004 & 591938 & 605261 & 626744 & 644177 & 654131 & 660816 & 662294 \\
\hline
\end{tabular}


Communications on Applied Electronics (CAE) - ISSN : 2394 - 4714

Foundation of Computer Science FCS, New York, USA

Volume 3 - No. 1, October 2015 - www.caeaccess.org

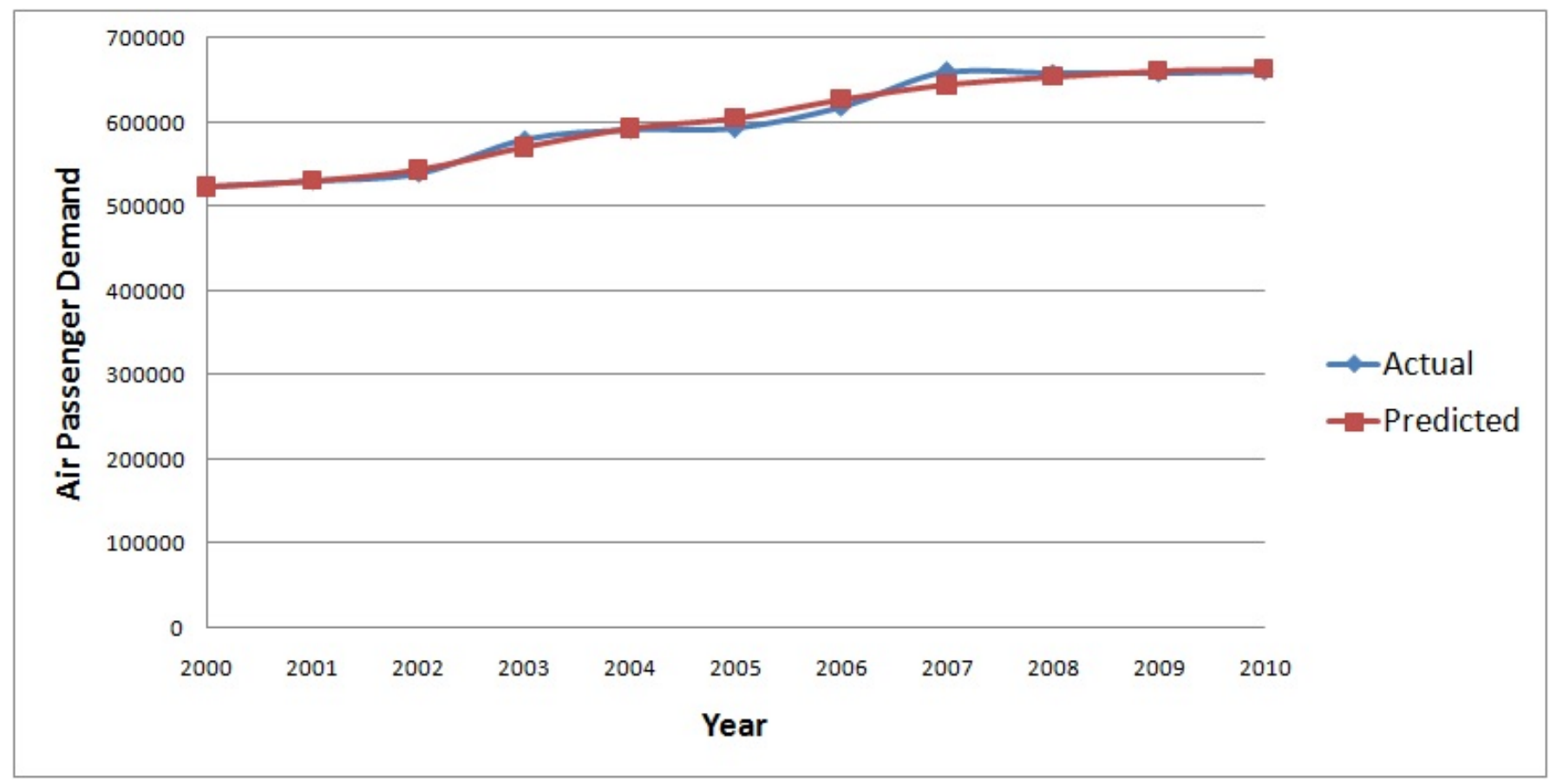

Fig. 3. Air Passenger Demand Forecasting after deleting four input variables 